\title{
Morphological and Molecular Characterization of Common Bean Landraces Varieties in South of Brazil
}

\section{Ana Claudia Schllemer dos Santos}

Universidade Tecnologica Federal do Parana

Lucas Vinícius de Sousa Alcântara

Universidade Tecnologica Federal do Parana

Larissa Yuki Terada

Universidade Tecnologica Federal do Parana

Isadora Bischoff Nunes

Universidade Tecnologica Federal do Parana

Lucas da Silva Domingues ( $\square$ lucassdomingues@gmail.com )

Universidade Tecnológica Federal do Paraná https://orcid.org/0000-0001-8594-354X

Joel Donazzolo

Universidade Tecnologica Federal do Parana

Juliana Morini Kupper Cardoso Perseguini

Universidade Tecnologica Federal do Parana

\section{Research Article}

Keywords: Phaseolus vulgaris, genetic variability, cluster analysis, microsatellites.

Posted Date: July 9th, 2021

DOl: https://doi.org/10.21203/rs.3.rs-671577/v1

License: (9) This work is licensed under a Creative Commons Attribution 4.0 International License. Read Full License 


\section{Abstract}

This work aimed to perform the morphological and molecular characterization of 31 land races varieties and 9 cultivars of common bean (Phaseolus vulgaris L.). Morphological characters were evaluated during seedling, flowering, physiological maturation and post-harvest maturation stages. Ten microsatellite markers were used for molecular screening. The markers were analyzed according to the number of alleles per locus, the allele frequency per locus and the polymorphism in content (PIC). Genetic distances and cluster analysis were performed using the Bayesian inference and the UPGMA method. All black beans evaluated have anthocyanin in the cotyledons, hypocotyls and stem, and their flowers are purple. For the growth habit, $50 \%$ of the evaluated genotypes belong to the type III and there is a predominance of yellow color in the pods ( $85 \%$ ) at the physiological maturation stage. Through the genetic dissimilarity it was possible to discriminate three groups for the Likelihood reason and six groups through the UPGMA method, these results indicate a wide genetic diversity among the evaluated genotypes.

\section{Introduction}

Common bean (Phaseolus vulgaris L.) is one of the most prominent leguminous food crop grown around the world, especially due to its high levels of minerals, vitamins, carbohydrates and fibers, in addition to being a great source of protein (Pereira et al. 2011). In Brazil, the consumption of beans is directly related to the grain characteristics, such as color, shape and size, as is the case of Carioca common bean, creamcolored grains with brown streaks, which is the most consumed type (Ribeiro et al. 2008).

The genetic diversity observed in common beans is wide for the plant's morphological characters and for the agronomic characters. Part of this variability is maintained in use by smallholder farmers, and the cultivation of these genotypes contributes with the conservation of genetic resources of common beans, which express greater adaptations to environmental conditions, resistance to diseases and may present high levels of nutrients in grains (Pereira et al. 2011).

In this sense, the genetic diversity found in these places must be added in germplasm banks in order to be characterized to indicate more promising genotypes for breeding programs. It can also improve the conditions of small farmers by allowing the rational use of these genotypes in agriculture familiar, in addition to preserving the genetic variability of common beans (Kloster et al. 2011).

The beans have two domestication centers, independent of each other, the Mesoamerican and the Andean, and they have very distinct morphological and molecular characteristics (Burle et al. 2010). The most striking differences between the two groups are the size of the seed and in the growth habit. This way, the study of the variability between genetic groups with their complete characterization assists in genetic breeding programs (Szilagyi et al. 2011).

Parenting selection can be assisted by different data analyzes based on plant's behavior, crossbreeding, or those of a predictive nature based on differences between the parents (morphological, physiological, 
molecular), using a measure of similarity or dissimilarity in order to evaluate the diversity between the genotypes (Correa and Gonçalves 2012).

Therefore, this work aimed to perform the morphological and molecular characterization of 31 land races varieties and 9 commercial cultivars of common bean, according to the genetic dissimilarity presented.

\section{Material And Methods}

The field experiment was conducted in the experimental area of the Universidade Tecnológica Federal do Paraná (Dois Vizinhos campus) ( $25^{\circ} 41^{\prime} \mathrm{S}, 53^{\circ} 05^{\prime} \mathrm{W}, 526 \mathrm{~m}$ above sea level), in the Southwest region of the state of Paraná, during dry crop season (second season) of 2018. The local soil is described as Red Latosol (Santos et al. 2013) with clay texture (773 g. $\mathrm{kg}^{-1}$ of clay). The climate of the region, according to the Köppen classification, is Cfa type, humid subtropical, with no defined dry season (Alvares et al. 2013). Annual precipitation for the region varies from 2,200 to 2,400 mm.year ${ }^{-1}$ (IAPAR, 2019) with a total of $453.6 \mathrm{~mm}\left(113.4 \mathrm{~mm} \cdot \mathrm{month}^{-1}\right)$ in the experiment period, with an average temperature of $19.75^{\circ} \mathrm{C}$.

Forty genotypes of common bean were evaluated, divided in thirty-one land races varieties and nine commercial cultivars (Fig. 1). The plants were grown under field conditions, like crops in the region, with seeds homogeneously distributed in the furrows, at a depth of approximately $2.5 \mathrm{~cm}$. The fertilization was carried out using $350 \mathrm{~kg} \mathrm{ha}^{-1}$ of the formula NPK (05-20-20) and was carried out in the sowing furrow with the use of a machine planter, right after the manual planting of the seeds. Cultural and phytosanitary managements were carried out to control weeds and pests, as well as nitrogen complementary fertilization, all cultural management were carried out according to the technical recommendations for common bean crop.

The experimental design used was randomized blocks, with three replications, with individual plants being evaluated within each repetition (block). The experimental plot was composed of two lines of four linear meters, with a distance of $0.45 \mathrm{~m}$ between them, totalling $3.6 \mathrm{~m}^{2}$ of useful area (per experimental plot), with 20 seeds distributed per linear meter to a final population of approximately 350,000 plants. ha $^{-}$ 1.

Morphological characters were evaluated in the seedling, flowering, physiological maturation, and postharvest stages. Evaluations of minimum descriptors were performed according to the Brazilian legislation of cultivar protection described by Silva (2005), composed by (i) commercial group; (ii) presence or absence of anthocyanin in cotyledons, hypocotyl and stem; (iii) growth habit; (iv) colour of wings and standard of flowers; (v) primary pod colour; (vi) number of days until flowering; (vii) cycle (number of days until physiological maturation); (ix) primary and secondary grain colours; (x) presence or absence of forehead venations; (xi) grain shape (spherical, elliptical or oblong/kidney shape); (xii) degree of flatness; (xiii) brightness; (xiv) presence or absence of halo; and (xv) halo colour; and (xvi) mass of 100 seeds. 
For molecular analysis, DNA was extracted from approximately $200 \mathrm{mg}$ of young and healthy leaves from one plant per plot with an E.Z.N.A.® - Plant DNA extraction kit (Omega Bio-Tek), following manufacturer's instructions. PCR (Polymerase Chain Reaction) analysis was performed with ten microsatellites markers (Table 1) and was carried out in a final volume of $15 \mu \mathrm{L}$, with $7.5 \mu \mathrm{L}$ of $5 \mathrm{x}$ FIREPoI ${ }^{\circledR}$ Master Mix, $1.5 \mu \mathrm{L}$ of ultrapure water, $4 \mu \mathrm{L}$ of genomic DNA, and $1 \mu \mathrm{L}$ of forward primer and 1 $\mu \mathrm{L}$ of primer reverse. Products of amplification were submitted to electrophoresis on a $2.8 \%$ agarose gel (1.4\% standard agarose and 1.4\% metpaphor agarose) in 1X TBE buffer (Tris/Borate/EDTA) stained with GelRed $^{\mathrm{T}} 1 \mathrm{X}$ (Biotium, Inc.), and its images were recorded with an ultraviolet transilluminator.

Microsatellite markers were analysed according to the number of alleles per locus, the allele frequency per locus and the polymorphism in content (PIC) given by the equation $P I C=1-\sum_{i=1}^{X} f i^{2}$, where $f i$ is the frequency of the $i$-th allele for a given band, added along the $n$ alleles (Lynch and Walsh 1998).

The reading of the polymorphic bands was performed according to the molecular weight of each allele, and with the aid of the ladder used (100bp Plus Opti-DNA Marker). The distances were calculated by the method described by Bruvo et al. (2014) and cluster analysis were performed using the UPGMA (Unweighted Pair Group Mean Average) method, using the DARwin Program version 6.0 (Perrier and Jacquemoud-Collet 2006). The representation of the forty genotypes was performed through the Bayesian inference with Structure software (Pritchard et al. 2000) with values ranging from $\mathrm{K}=2$ to $\mathrm{K}=$ 10. Five repetitions were performed for each $K$ value, using the No admixture model with 200,000 burn in periods and 500,000 Markov Chain Monte Carlo simulations (MCMC). To verify which $\mathrm{K}$ was the most appropriate to infer the clusters, the likelihood ratio (LnPD) was calculated, according to the criteria proposed by Evanno et al. (2005). Descriptive analysis was used for morphological parameters, with data presentation according to the form of minimum morphological descriptors of common bean, according to Silva (2005).

\section{Results}

Minimum descriptors showed that thirteen genotypes (32.5\%) were classified as Black, ten (25\%) as Carioca, one (2.5\%) as Rosinha, one (2.5\%) as Pinto, one (2.5\%) as Mulatinho, two (5\%) as Red, and twelve (30\%) as Others (brindle and other colours) (Table 2). Five genotypes (12.5\%) were classified with growth habit type I (determined growth and shrub size), fifteen (37.5\%) under type II (erect and shrubby growth, presence of guides with more than 12 knots), twenty (50\%) under type III (prostrate or semicreeper growth, with shrub bearing in favourable environments and longer guides than type II) and none under type IV (climber and undetermined) (Table 2). Nineteen genotypes (47.5\%) had purple flowers, seventeen (42.5\%) white flowers and four (10\%) pink flowers (Table 2). Five genotypes (12.5\%) displayed purple as primary pod colour, thirty-four (85\%) displayed yellow and just one (2.5\%) displayed red (Table 2). Number of days until flowering (NDF) varied from 35 to 48 days with one genotype (2.5\%) classified as early cycle ( $<75$ days from emergence to maturation), six $(15 \%)$ as semi-early cycle ( 75 to 85 days), thirty-one (77.5\%) as normal cycle (86 to 95 days) and two (5\%) as late cycle (> 95 days). 
Morphological descriptors showed that seventeen genotypes (42,5\%) presented primary and secondary grain colours (varying from cream to reddish brown for primary colour and pink to black as secondary) while twenty-three genotypes $(57,5 \%)$ were uniform in their grain colour (varying from cream to black) (Table 3). Most of the genotypes (87,5\%) presented forehead venations, elliptical (65\%), half-full (65\%) and opaque $(70 \%)$ grains with the presence of halo $(100 \%)$ and mass of one hundred grains variating between $18.07 \mathrm{~g}$ and $29.37 \mathrm{~g}$ (Table 3 ). Of the $35 \%$ of flat grains, half were from Black group and the other half from Carioca and Others groups (Table 3 ).

For molecular analysis, all ten microsatellites showed a polymorphic pattern where 43 polymorphic bands were generated, with 2 to 6 alleles, with an average of 4.2 alleles per locus (Table 4 ). The markers evaluated in the present study were considered according to Botstein et al. (1980), as moderately informative to very informative, with the marker SSR-IAC183 being the most informative (0.66) and the least informative being SSR-IAC168 (0.33), with an average value of 0.56 (Table 4).

Genotypes were divided into three groups $(\mathrm{K}=3)$ according to the Bayesian inference (Fig. 2). Group 1 is primarily composed by commercial cultivars and land races with Andean origin, group 2 is predominantly formed by land races with Mesoamerican origin and group 3 had similar organization to group 1, with commercial cultivars and land races with Andean origin (Fig. 2). The presence of Chumbinho, Pombinho, Vagem Roxa Seca and Carioca rosa was not expected in group 3 once that their morphological descriptors tend to fit the Mesoamerican origin.

The resulting dendrogram revealed high variability among genotypes, divided into six clusters (Fig. 3). Two clusters were formed with a large number of landraces varieties (cluster 3 and 4) with characteristics of Mesoamerican common beans. A cluster predominant formed by commercial cultivars (group 5) and three smaller cluster formed by two land races each with characteristics similar to genotypes from Andean origin (groups 1, 2 and 6).

The largest cluster 3 and 4 are formed predominantly by varieties from the commercial groups Black and Carioca groups (approximately $70 \%$ in each group) (Fig. 3). These groups too presented growth habits type II and type III, semi-early to normal cycle (Table 2), elliptical and half-flat grains (Table 3). Genotypes in these cluster also presented predominate elliptical and opaque grains. In group 3 , only the Carioca rosa had glossy grains and only the Gralha Coop variety had grains of Short oblong format. In Group 4, all varieties that presented non-elliptic grains also presented Glossy grains (Table 3).

Most of the commercial cultivars evaluated in this study were in cluster 5 (Fig. 3) with growth habits type II and type III, normal to late cycles (Table 2), elliptical, half-flat, and opaque grains (except for Mourinho that had intermediate grains) (Table 3 ).

Genotypes in cluster 1, 2 and 6 (Fig. 3) present no elliptical, semi-flat or semi-flat grains (Table 3) with semi-early cycle (Table 2 ). Genotypes in these clusters presented large beans (> $14 \mathrm{~mm}$ in length) (Table 3), semi-early cycle and type I growth habit (Table 2). All characteristics of Andean center of origin 
Genotypes of cluster 2 consisted of two land races with normal cycle and type I growth habit (IPR Rajado) and semi-early cycle and type I growth habit (Cavalo BR UM), both with pink flowers (Table 2). Both presented large, oblong, opaque, and semi-flattened grains (Table 3). Similar characteristics to cycle, growth habit and grain characteristics are present in the genotypes off 1 and 6 clusters (Fig. 3). It is believed that this groups also had Andean center of origin. but even with their genetic differences, they still present highly conserved parts, being grouped together under Bayesian analysis (Fig. 2).

The genotypes Pardinho and Gralha Coop with normal cycle, type III growth habit, yellow pods (Table 2), opaque grains and similar mass of 100 grains (Table 3). These two genotypes were also together under Bayesian analysis (group 2), showing how genetically similar these genotypes were (Figs. 2 and 3). The Genotypes Campos Gerais and IPR Bentevi that are in the cluster together whit the land races varieties consisted of two commercial cultivars from IAPAR, which belong to Carioca Group, with normal cycle and type III growth habit (Table 2), with opaque and elliptical grains colored with similar shades of cream and brown (Table 3).

Both Bayesian (Fig. 2) and UPGMA (Fig. 3) analysis revealed the diversity that exists between the studied genotypes and the elevated similarity among them, with some minor exceptions. However, UPGMA analysis (Fig. 3) provided better discrimination of genotypes within the Bayesian groups (Fig. 2), where genotypes were primarily grouped by their centres of Origin.

\section{Discussion}

The morphological and molecular differences detected in this study corroborate the results found by others (Campos et al. 2011) who, through the use of microsatellites, observed the presence of genetic variability for common beans in Brazil, showing more the presence of a great genetic variability for local common beans. For breeding programs, the greater the diversity the better, with the possibility of greater gains. Thus, this variability can be used by researchers and/or breeders to perform new crossings to generate elite cultivars, meeting the needs of farmers and consumers (Cardoso 2009).

Analyzing the morphological characteristics, the presence of anthocyanin in parts of the plant was observed, as well as studied (Afonso 2010), on the physical-chemical characterization and antioxidant activity of new bean varieties, detecting that bean cultivars that present grains of dark colored (Fig. 1) had a higher amount of anthocyanins (pigmentation) than the light colored grain bean cultivars.

Common bean cycle can vary from 65 to 120 days, depending on the genotype, edaphoclimatic conditions, and crop season, so it is possible to have three crop seasons during the year, depending on the region (Monteiro et al. 2010). In this study there was a condensation of genotypes with normal cycle, with only a few extremes, with five varieties of early cycle and two with late cycle (Table 2).

Studies confirm that there are regional preferences in some locations in the South of Brazil (Marques et al. 1996), where low and medium technological rural producers and family farming are concentrated. 
genotypes classified under Black grains group. Black grains also have a nutraceutical appeal once that dark-colored bean have higher anthocyanins content than light-colored ones (Afonso 2010). Besides the nutraceutical appeal, buyers also rely on the visual appeal of grains. Differences in the preferences among all regions of Brazil leads to the large variety of morphological traits as color (one or two), form, shine and presence or absence of other traits as streaks or spots (Silva and Costa 2003).

This variability was observed within evaluated genotypes. In Brazil, Black and Carioca groups are the most accepted ones, tending to have elliptical and semi-flattened grains (Carbonell et al. 2010). The Carioca group with beige grains with brown streaks is the most consumed in Brazil, as lighter colored grains were correlated to the preference for consumption and the commercial value of the product Ribeiro et al. (2008). This was partially reflected in this study with the Carioca beans being the second most predominant group.

In terms of molecular characteristics, the degree of polymorphism between possible parents can be used to indicate/select recombinant genotypes based on the studied markers (Pereira et al. 2007). The results found for the microsatellites: SSR-IAC65, SSR-IAC67, SSR-IAC183 and SSR-IAC239, are superior to the results found by other authors (Perseguini et al. 2011) for Carioca beans, where the authors detected the absence polymorphism for the SSR-IAC67 marker. However, this marker was polymorphic and had the second highest PIC of the evaluated SSRs, presenting four alleles, showing a greater diversity among evaluated genotypes in this study. Other authors obtained an average of 7.8 alleles per polymorphic locus, ranging from two to 24 polymorphic alleles when using a greater number of SSR markers (150 markers, 129 being polymorphic) (Blair et al. 2006).

As well as characterizing the cultivated germplasm of $P$. vulgaris (Mota et al. 2011), they used 36 markers and 150 accessions evaluated in five trials, of which 34 markers were polymorphic and 24 were used, identifying 190 alleles, with an average of 7,92 alleles per polymorphic locus, ranging from three to 17 alleles for locus BM154.

When characterizing grains of the Carioca group as belonging to the center of Mesoamerican origin, (Carvalho et al., 2008), they emphasize that the genetic basis of bean breeding programs in Brazil comes from Mesoamerican accessions. This also occur in the results found in the present study, as grains of the carioca type were not grouped in the center of Andean origin, separated to genotypes with larger grains.

Many studies have been carried out in recent years to characterize bean genotypes in relation to their domestication centers (Coelho et al. 2007; Barelli et al. 2009; Cabral et al. 2011) evaluated the diversity of bean genotypes using microsatellite markers and managed to group the genotypes according to the domestication centers. Researching the implications of univariate and multivariate analysis on the dissimilarity of bean accessions (Grigolo et al. 2018) has also been successful in grouping bean genotypes according to their centers of origin.

UPGMA separated the two commercial cultivars from IAPAR from the others (Fig. 2), that belong to the different objectives, and in the case of IAPAR 
they aimed to obtain cultivars resistant to drought (Cardoso, 2009). It is believed that similar parents were used in crosses that gave rise to these cultivars and, therefore, present genetic similarity to each other. In this study there were also clusters formed by similar genotypes, both for morphologically similar varieties and for cultivars and their breeders.

The predominant morphological characteristics that most impacted the separation of the groups were morphological grain traits as its shape, degree of flattening, color, brightness, color of the flower, of the pods, growth habit and cycle. These results corroborate the grouping performed by (Kloster et al. 2011), with common bean cultivars, and it also relates their grouping to the two centers of origin of the common bean (Andean and Mesoamerican).

\section{Conclusion}

The evaluated genotypes showed morphological differences, characteristic to their commercial group and Center of Origin, showing the genetic variability present in this study.

Through the genetic dissimilarity among the forty common bean genotypes studied it was possible to discriminate the genotypes in three in the Bayesian analysis and six by the UPGMA. These results confirm the existing genetic diversity. among the evaluated genotypes also by molecular analysis.

Thus, it was possible to molecularly characterize the 40 common bean genotypes studied, based on UPGMA and Bayesian cluster analysis, verifying that both methodologies are complementary, discriminating groups based on their centers of origin and according to morphological characteristics.

\section{Declarations}

The authors of this article are honoured to submit this paper for review by this relevant Journal. We consent the participation, submission and publication. We also declare that there are no conflicts of interest between the authors for the submission and the research was funded by the Conselho Nacional de Desenvolvimento Científico e Tecnológico- Cnpq (National Scientific and Technological Development Council) from Brazil and by the Universidade Tecnológica Federal do Paraná (Federal University of Technology -UTFPR).

We are also committed to adhering to the information transparency policy when providing the data used in the development of this research.

For the other items in which declarations for submission are requested, Code availability and Ethics approval does not apply any declaration by the authors. 
Arra Clandia S dos sontos.

Ana Claudia Schellmer dos Santos

LUAS V.S.ALCANTARA

Lucas Vinícius de Sousa Alcantara

Lariessa Yuki Terodo-

Larissa Yuki Terada

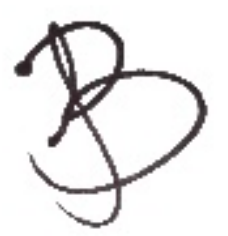

Isadora Bischoff Nunes

Loading [MathJax]/jax/output/CommonHTML/fonts/TeX/fontdata.js

Page $9 / 23$ 
LUCAS DAS. DOMINGUES

Lucas da Silva Domingues*

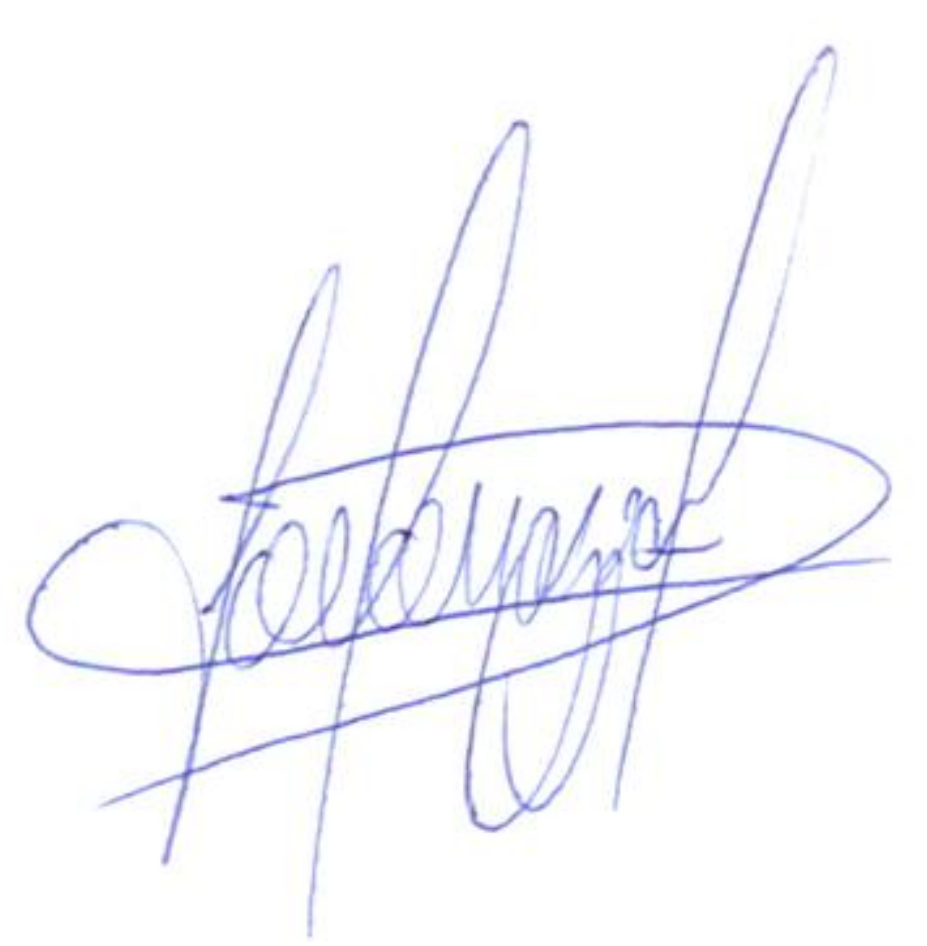

Joel Donazzolo

Ara Clandia 5 dos sontos.

Loading [MathJax]/jax/output/CommonHTML/fonts/TeX/fontdata.js 
Juliana Morini Kupper Cardoso Perseguini

\section{References}

1. Afonso SME (2010) Caracterização físico-química e atividade antioxidante de novas variedades de feijão (Phaseolus vulgaris L.). Tese. Instituto Politécnico de Bragança, Escola Superior Agrária

2. Alvares CA, Stape JL, Sentelhas PC, Gonçalves JLM, Sparovek G (2013) Köppen's climate classification map for Brazil. Meteorol Z 22:711728

3. Barelli MAA, Gonçalves-Vidigal MC, Vidigal Filho PS, Neves LG, Silva HT (2009) Genetic divergence in common bean landrace cultivars from Mato Grosso do Sul State. Semina: Ciências Agrárias 30:1061-1072

4. Blair MW, Giraldo MC, Buendia HF, Tovar E, Duque MC, Beebe SE (2006) Microsatellite marker diversity in common bean (Phaseolus vulgaris L.). Theorical Applied Genetic 113:100-109

5. Botstein D, White RL, Skolmick H, Davis RW (1980) Construction of a genetic linkage map in man using restriction fragment length polymorphism. Am J Hum Genet 32:314-331

6. Bruvo R, Michiels NKD, 'Souza TG, Schulenburg H (2004) A simple method for the calculation of microsatellite genotype distances irrespective of ploidy level. Mol Ecol 13:2101-2106

7. Burle ML, Fonseca JR, Kami JA, Gepts $\mathrm{P}$ (2010) Microsatellite diversity and genetic structure among common bean (Phaseolus vulgaris L.) landraces in Brazil, a secondary center of diversity. Theor Appl Genet 121:801-813

8. Cabral PDS, Soares TCB, Lima ABP, Alves DS, Nunes JA (2011) Diversidade genética de acessos de feijão comum por caracteres agronômicos. Fortaleza: Revista Ciência Agronômica 42:898-905

9. Campos T, Oblessuc PR, Sforça DA, Cardoso JMK, Baroni RM, Sousa ACB, Carbonell SAM, Chioratto AF, Garcia AAF, Rubiano LB, Souza AP (2011) Inheritance of growth habit detected by genetic linkage analysis using microsatellites in the common bean (Phaseolus vulgaris L.). Molecular breeding 27:549-560

10. Carbonell SAM, Chiorato AF, Gonçalves JGR, Perina EF, Carvalho CRL (2010) Tamanho de grão comercial em cultivares de feijoeiro. Ciência Rural 40:2067-2073

11. Cardoso JMK (2009) Estimativa da Diversidade Genética entre Acessos do Tipo Carioca de Feijão Comum com Base em Marcadores Moleculares. Dissertação, Instituto Agronômico Pós-graduação

12. Carvalho MF, Crestani M, Farias FL, Coimbra JLM, Bogo A, Guidolin AF (2008) Caracterização da diversidade genética entre acessos crioulos de feijão (Phaseolus vulgaris L.) coletados em Santa Catarina por marcadores RAPD. Ciência Rural 38:1522-1528

13. Coelho CMM, Coimbra JLM, Souza CA, Bogo A, Guidolin AF (2007) Diversidade genética em acessos de feijão (Phaseolus vulgaris L.). Ciência Rural 37:1241-1247 
14. Chiorato AF (2004) Divergência genética em acessos de feijoeiro (Phaseolus vulgaris L.) do Banco de Germoplasma do Instituto Agronômico-IAC. 2004. Dissertação, Instituto Agronômico

15. Correa AM, Gonçalves MC (2015) Divergência genética em genótipos de feijão comum cultivados em Mato Grosso do Sul. Ceres 59:206-212

16. Evanno G, Regnaut S, Goudet J (2005) Detecting the number of clusters of individuals using the software STRUCTURE: a simulation study. Molecular ecology 14:2611-2620

17. Grigolo S, Fioreze ACCL, Denardi S, Vacari J (2018) Implicações da análise univariada e multivariada na dissimilaridade de acessos de feijão comum. Revista de Ciências Agroveterinárias 17:351-360

18. Iapar. Instituto Agronômico do Paraná. Atlas Climático do Estado do Paraná (2019) http://www.iapar.br/arquivos/File/zip_pdf/agrometeorologia/2019-02-Atlas.pdf. Acessado em 24 abril de 2019

19. Kloster GS, Barelli MAA, Silva CR, Neves LG, Sobrinho SP, Luz PB (2011) Análise da divergência genética através de caracteres morfológicos em cultivares de feijoeiro. Revista Brasileira de Ciências Agrárias, 6: 452-459

20. Lynch M, Walsh B (1998) Genetics and analysis of quantitative traits. Sinauer Associates, Sunderland

21. Marques BEV, Santos AF, Vargas AAT, Candal Neto JF (1996) 'EMCAPA 406 - Xamego'. Nova cultivar de feijão preto para o Espírito Santo. Emcapa, Vitória: 4 p. (Comunicado Técnico, 81).

https://biblioteca.incaper.es.gov.br/digital/bitstream/item/1385/1/BRT-comunicadotecnico-n81Emcapa.pdf. Acessado em 25 de abril de 2019

22. Monteiro ER, Bastos EM, Lopes ACA, Gomes RLF, Nunes JAR (2010) Diversidade genética entre acessos de espécies cultivadas de pimentas. Ciência Rural 40:288-293

23. Moreira RMP, Ferreira JM, Takahashi LSA, Vanconcelos MEC, Geus LC, Botti L (2009) Potencial agronômico e divergência genética entre genótipos de feijão-vagem de crescimento determinado. Semina: Ciências Agrárias, 30: 1051-1060

24. Mota A, Menezes IPP, Veiga MMA, Brondani C, Borba TDO, Pereira HS, Vianello R (2011) Caracterização de germoplasma cultivado de Phaseolus vulgaris que compõem ensaios de VCU utilizando marcadores microssatélites. In: Embrapa Arroz e Feijão-Artigo em anais de congresso (ALICE). In: Congresso Nacional De Pesquisa De Feijão, Goiânia. Anais... Goiânia: Embrapa Arroz e Feijão. https://ainfo.cnptia.embrapa.br/digital/bitstream/item/51940/1/biotc4.pdf. Acessado em 25 de abril de 2019

25. Pacheco RS, Brito LF, Ferreira EDB, Straliotto R, Araújo A (2012) Crescimento e produção de cultivares de feijoeiro sob inoculação com rizóbio em comparação à adubação nitrogenada. In: Embrapa Arroz e Feijão-Artigo em anais de congresso (ALICE). In: Reunião Brasileira De Ciência Do Solo E Nutrição De Plantas, 30.; Reunião Brasileira Sobre Micorrizas, 14.; Simpósio Brasileiro De Microbiologia Do Solo, 12.; Reunião Brasileira De Biologia Do Solo, 9.; Simpósio Sobre Selênio No Brasil, Maceió. A responsabilidade socioambiental da pesquisa agrícola: Anais... Viçosa, MG: SBCS. 
26. Pereira HS, Santos JB, Abreu AFB, Couto KR (2007) Informações fenotípicas e marcadores microssatélites de QTL na escolha de populações segregantes de feijoeiro. Pesquisa agropecuária brasileira $42: 707-713$

27. Pereira T, Coelho CM, Santos JP, Bogo A, Miquelluti D (2011) Diversidade no teor de nutrientes em grãos de feijão crioulo no Estado de Santa Catarina. Acta Scientiarum Agronomy 33:477-485

28. Perrier $X$, Jacquemoud-Collet JP (2006) DARwin software

29. Perseguini JMKC, Chioratto AF, Zucchi MI, Colombo CA, Carbonell SAM, Mondego JMC, Gazaffi R, Garcia AAF, Campos T, Souza AP, Rubiano LB (2011) Genetic diversity in cultivated carioca common beans based on molecular marker analysis. Genetics molecular biology 34:88-102

30. Pritchard JK, Stephens M, Donnelly P (2000) Inference of population structure using multilocus genotype data. Genetics 155:945-959

31. Ribeiro ND, Storck L, Poersch NL (2008) Classificação de lotes comerciais de feijão por meio da claridade do tegumento dos grãos. Ciência Rural 38:2042-2045

32. Santos HG, Jacomine PKT, Anjos LHC, Oliveira VA, Lumbreras JF, Coelho MR, Almeida J, Cunha TJF, Oliveira JB (2013) Sistema brasileiro de classificação de solos. $3^{\text {a }}$ Ed. Embrapa, Brasília. 353p

33. Silva HT (2005) Descritores mínimos indicados para caracterizar cultivares/variedades de feijão comum (Phaseolus vulgaris L.) 2005. Embrapa Arroz e Feijão, Santo Antônio de Goiás, 32p

34. Silva HT, Costa AO (2003) Caracterização botânica de espécies silvestres do gênero Phaseolus L. (Leguminosae). Embrapa Arroz e Feijão, Santo Antônio de Goiás, Documentos 156

35. Szilagyi L, Tayyar Ş, Ciucă M (2011) Evaluation of genetic diversity in common bean (Phaseolus vulgaris L.) using RAPD markers and morpho-agronomic traits. Romanian Biotechnol Lett 16:98105

\section{Tables}

Table 1 Data from ten microsatellites markers used for DNA amplification of forty common bean genotypes (Phaseolus vulgaris L.) with their respective annealing temperature $\left(T A{ }^{\circ} \mathrm{C}\right)$. 


\begin{tabular}{|lllll|}
\hline$N^{\circ}$ & SSR nomenclature & Reason & TA $^{\circ} \mathrm{C}$ & Authors \\
\hline 01 & SSR-IAC67 & $(\mathrm{GT}) 7$ & 56 & PERSEGUINI et al. (2011) \\
\hline 02 & SSR-IAC183 & $(\mathrm{AG}) 18$ A (AC) 4 & 56 & PERSEGUINI et al. (2011) \\
\hline 03 & SSR-IAC268 & $(\mathrm{TC}) 9$ & 56 & CAMPOS et al. (2011) \\
\hline 04 & SSR-IAC245 & $(\mathrm{AT}) 2(\mathrm{GT}) 3$ & 56 & CAMPOS et al. (2011) \\
\hline 05 & SSR-IAC284 & $(\mathrm{CT}) 13$ & 56 & CAMPOS et al. (2011) \\
\hline 06 & SSR-IAC262 & $(\mathrm{GT}) 9$ & 56 & CAMPOS et al. (2011) \\
\hline 07 & SSR-IAC276 & $(\mathrm{GAA}) 4(\mathrm{GT}) 7$ & 56 & CAMPOS et al. (2011) \\
\hline 08 & SSR-IAC282 & $(\mathrm{CAA}) 2 \mathrm{~T}(\mathrm{CA}) 3$ & 56 & CAMPOS et al. (2011) \\
\hline 09 & SSR-IAC65 & $(\mathrm{TG}) 5$ & 56 & PERSEGUINI et al. (2011) \\
\hline 10 & SSR-IAC239 & $(\mathrm{AG}) 15$ & 56 & PERSEGUINI et al. (2011) \\
\hline
\end{tabular}

Table 2 Minimum descriptors of common bean (Phaseolus vulgaris L.): commercial group (CG), growth habit (GH), presence of anthocyanin (ANT), flower colour (wing and standard - FC), primary pod colour (PPC), number of days to flowering (NDF), and number of days from emergence to harvest maturity (CYCLE). 


\begin{tabular}{|c|c|c|c|c|c|c|c|}
\hline \multirow[t]{2}{*}{ Genotype } & \multicolumn{7}{|c|}{ Minimum descriptors } \\
\hline & CG & $\mathrm{GH}$ & ANT & FC & PPC & NDF & CYCLE \\
\hline Serrana Vagem Roxa & Black & II & Present & Purple & Purple & $\begin{array}{l}48 \\
\text { days }\end{array}$ & 90 days \\
\hline 90 Dias Preto & Black & II & Present & Purple & Yellow & $\begin{array}{l}47 \\
\text { days }\end{array}$ & 94 days \\
\hline Rosinha & Rosinha & II & Absent & White & Yellow & $\begin{array}{l}48 \\
\text { days }\end{array}$ & 95 days \\
\hline Vagem Branca Lustroso & Black & III & Present & Purple & Yellow & $\begin{array}{l}35 \\
\text { days }\end{array}$ & 75 days \\
\hline Carioca Siriri & Carioca & III & Absent & White & Yellow & $\begin{array}{l}43 \\
\text { days }\end{array}$ & 85 days \\
\hline Carioca Um Rajado & Others & II & Present & Purple & Purple & $\begin{array}{l}43 \\
\text { days }\end{array}$ & 85 days \\
\hline Cavalo BR UM & Others & I & Absent & Pink & Yellow & $\begin{array}{l}35 \\
\text { days }\end{array}$ & 74 days \\
\hline Chumbinho Preto & Black & III & Present & Purple & Yellow & $\begin{array}{l}44 \\
\text { days }\end{array}$ & 87 days \\
\hline Gralha Coop & Black & III & Present & Purple & Yellow & $\begin{array}{l}43 \\
\text { days }\end{array}$ & 95 days \\
\hline Pardinho Mineiro & Others & III & Absent & White & Yellow & $\begin{array}{l}44 \\
\text { days }\end{array}$ & 95 days \\
\hline Argentino & Red & 1 & Absent & White & Yellow & $\begin{array}{l}36 \\
\text { days }\end{array}$ & 79 days \\
\hline Mourinho & Others & II & Absent & Purple & Yellow & $\begin{array}{l}44 \\
\text { days }\end{array}$ & 95 days \\
\hline Taquara & Black & ॥ & Present & Purple & Yellow & $\begin{array}{l}42 \\
\text { days }\end{array}$ & 95 days \\
\hline Serrana Vagem Branca & Black & II & Present & Purple & Yellow & $\begin{array}{l}41 \\
\text { days }\end{array}$ & 89 days \\
\hline lapar 40 & Carioca & III & Absent & White & Yellow & $\begin{array}{l}43 \\
\text { days }\end{array}$ & 95 days \\
\hline Maronze & Others & III & Absent & White & Yellow & $\begin{array}{l}43 \\
\text { days }\end{array}$ & 95 days \\
\hline Carioca lapar 16 & Carioca & 1 & Absent & White & Yellow & $\begin{array}{l}41 \\
\text { days }\end{array}$ & 95 days \\
\hline $\begin{array}{l}\text { Chumbinho Preto } \\
\text { Lustroso }\end{array}$ & Black & III & Present & Purple & Purple & $\begin{array}{l}41 \\
\text { days }\end{array}$ & 95 days \\
\hline
\end{tabular}




\begin{tabular}{|c|c|c|c|c|c|c|c|}
\hline Pardinho & Others & III & Absent & White & Yellow & $\begin{array}{l}41 \\
\text { days }\end{array}$ & 88 days \\
\hline Carioca Vermelho & Others & II & Present & Purple & Purple & $\begin{array}{l}42 \\
\text { days }\end{array}$ & 87 days \\
\hline Gralha MST & Black & II & Present & Purple & Yellow & $\begin{array}{l}44 \\
\text { days }\end{array}$ & 88 days \\
\hline Vinagrinho & Others & II & Absent & Purple & Yellow & $\begin{array}{l}44 \\
\text { days }\end{array}$ & 95 days \\
\hline Cavalo UM PR & Others & II & Absent & Pink & Yellow & $\begin{array}{l}39 \\
\text { days }\end{array}$ & 87 days \\
\hline IPR Rajado & Others & I & Absent & Pink & Yellow & $\begin{array}{l}37 \\
\text { days }\end{array}$ & 79 days \\
\hline Chumbinho & Black & III & Present & Purple & Yellow & $\begin{array}{l}47 \\
\text { days }\end{array}$ & 95 days \\
\hline Vermelho & Red & I & Absent & Pink & Yellow & $\begin{array}{l}36 \\
\text { days }\end{array}$ & 79 days \\
\hline Pombinho & Others & III & Absent & White & Red & $\begin{array}{l}43 \\
\text { days }\end{array}$ & 102 days \\
\hline Vagem Roxa Seca & Black & III & Present & Purple & Purple & $\begin{array}{l}41 \\
\text { days }\end{array}$ & 87 days \\
\hline Mulatinho & Mulatinho & II & Present & Purple & Yellow & $\begin{array}{l}42 \\
\text { days }\end{array}$ & 88 days \\
\hline Carioca Rosa & Others & III & Absent & Purple & Yellow & $\begin{array}{l}46 \\
\text { days }\end{array}$ & 100 days \\
\hline Carijó & Pinto & III & Absent & White & Yellow & $\begin{array}{l}44 \\
\text { days }\end{array}$ & 95 days \\
\hline Bem-te-vi & Carioca & III & Absent & White & Yellow & $\begin{array}{l}44 \\
\text { days }\end{array}$ & 90 days \\
\hline Campos Gerais & Carioca & III & Absent & White & Yellow & $\begin{array}{l}46 \\
\text { days }\end{array}$ & 88 days \\
\hline ANFC 9 & Carioca & III & Absent & White & Yellow & $\begin{array}{l}46 \\
\text { days }\end{array}$ & 95 days \\
\hline Nhambu & Black & II & Present & Purple & Yellow & $\begin{array}{l}39 \\
\text { days }\end{array}$ & 90 days \\
\hline Bola Cheia & Carioca & III & Absent & White & Yellow & $\begin{array}{l}44 \\
\text { days }\end{array}$ & 90 days \\
\hline Quero-quero & Carioca & III & Absent & White & Yellow & $\begin{array}{l}43 \\
\text { days }\end{array}$ & 90 days \\
\hline $\begin{array}{l}\text { RRS Fstein } \\
\text { Loading [MathJax]/jax/ol }\end{array}$ & $\begin{array}{l}\text { Carinca } \\
\text { onHTML/font }\end{array}$ & 11 & $\begin{array}{l}\text { Ahsent } \\
\text { lata.js }\end{array}$ & White & Yellow & $\begin{array}{l}44 \\
\text { days }\end{array}$ & 90 days \\
\hline
\end{tabular}




\begin{tabular}{|c|c|c|c|c|c|c|c|}
\hline BRS Dama & Carioca & III & Absent & White & Yellow & $\begin{array}{l}43 \\
\text { days }\end{array}$ & 95 days \\
\hline BRS Expedito & Black & II & Present & Purple & Yellow & $\begin{array}{l}41 \\
\text { days }\end{array}$ & 88 days \\
\hline
\end{tabular}

Table 3 Morphological descriptors for common bean (Phaseolus vulgaris L.), primary (\%PC) and secondary (\%SC) colours, presence of forehead venations (PFV), shape (S), degree of flatness (DF), brightness $(B)$, halo $(H)$, and mass of one hundred grains (MHG). 


\begin{tabular}{|c|c|c|c|c|c|c|c|}
\hline Genotpype & (\%PC and \%SC) & PFV & $S$ & DF & B & $\mathrm{H}$ & $\begin{array}{l}\text { MHG } \\
(\mathrm{g})\end{array}$ \\
\hline Serrana Vagem Roxa & $100 \%$ Black & $\mathrm{P}$ & $\mathrm{El}$ & $\mathrm{F}$ & 0 & $P$ & 21.47 \\
\hline 90 Dias Preto & $100 \%$ Black & $\mathrm{P}$ & El & $\mathrm{F}$ & 0 & $P$ & 21.10 \\
\hline Rosinha & $100 \%$ Pink & $\mathrm{P}$ & So & $\mathrm{Hf}$ & G & $P$ & 18.07 \\
\hline Vagem Branca Lustroso & $100 \%$ Black & A & Sf & $\mathrm{F}$ & $\mathrm{G}$ & $P$ & 19.23 \\
\hline Carioca Siriri & $60 \%$ Cream and $40 \%$ Brown & $\mathrm{P}$ & $\mathrm{El}$ & $\mathrm{F}$ & 0 & $P$ & 21.90 \\
\hline Carioca Um Rajado & $\begin{array}{l}80 \% \text { Reddish brown and } 20 \% \\
\text { Black }\end{array}$ & $\mathrm{P}$ & $\mathrm{El}$ & $\mathrm{Hf}$ & 0 & $P$ & 18.47 \\
\hline Cavalo BR UM & $60 \%$ Cream and $40 \%$ Pink & $\mathrm{P}$ & $\mathrm{Ob}$ & $\mathrm{Hf}$ & 1 & $P$ & 29.37 \\
\hline Chumbinho Preto & $100 \%$ Black & A & Sf & $\mathrm{Hf}$ & G & $P$ & 21.33 \\
\hline Gralha Coop & $100 \%$ Black & A & So & $\mathrm{F}$ & 0 & $P$ & 20.23 \\
\hline Pardinho Mineiro & $100 \%$ Greenish brown & $P$ & $\mathrm{El}$ & $\mathrm{Hf}$ & 0 & $P$ & 19.10 \\
\hline Argentino & $100 \%$ Red & $\mathrm{P}$ & So & $\mathrm{Hf}$ & I & $P$ & 24.63 \\
\hline Mourinho & 100\% Grayish & A & $\mathrm{El}$ & $\mathrm{Hf}$ & I & $P$ & 22.80 \\
\hline Taquara & $100 \%$ Black & $\mathrm{P}$ & $\mathrm{El}$ & $\mathrm{F}$ & 0 & $P$ & 21.63 \\
\hline Serrana Vagem Branca & $100 \%$ Black & $\mathrm{P}$ & $\mathrm{El}$ & $\mathrm{F}$ & 0 & $P$ & 21.50 \\
\hline lapar 40 & $80 \%$ Cream and $20 \%$ Brown & $\mathrm{P}$ & $\mathrm{El}$ & $\mathrm{Hf}$ & 0 & $P$ & 25.47 \\
\hline Maronze & $100 \%$ Brown & $\mathrm{P}$ & $\mathrm{El}$ & $\mathrm{Hf}$ & 0 & $P$ & 19.10 \\
\hline Carioca lapar 16 & $70 \%$ Cream and $30 \%$ Brown & $\mathrm{P}$ & $\mathrm{El}$ & $\mathrm{Hf}$ & 0 & $P$ & 25.53 \\
\hline $\begin{array}{l}\text { Chumbinho Preto } \\
\text { Lustroso }\end{array}$ & $100 \%$ Black & A & Sf & $\mathrm{Hf}$ & 1 & $\mathrm{P}$ & 22.03 \\
\hline Pardinho & 100\% Light Brown & $\mathrm{P}$ & $\mathrm{El}$ & $\mathrm{F}$ & 1 & $\mathrm{P}$ & 23.83 \\
\hline Carioca Vermelho & $\begin{array}{l}80 \% \text { Reddish brown and } 20 \% \\
\text { Black }\end{array}$ & $\mathrm{P}$ & $\mathrm{El}$ & $\mathrm{Hf}$ & I & $\mathrm{P}$ & 22.23 \\
\hline Gralha MST & $100 \%$ Black & $\mathrm{P}$ & $\mathrm{El}$ & $\mathrm{F}$ & 0 & $\mathrm{P}$ & 21.10 \\
\hline Vinagrinho & $100 \%$ Red & $\mathrm{P}$ & Sf & $\mathrm{F}$ & G & $\mathrm{P}$ & 20.80 \\
\hline Cavalo UM PR & $80 \%$ Red and $20 \%$ Black & $\mathrm{P}$ & $\mathrm{Ob}$ & $\mathrm{Hf}$ & 0 & $P$ & 27.17 \\
\hline IPR Rajado & $80 \%$ Cream and $20 \%$ Red & $\mathrm{P}$ & So & $\mathrm{Hf}$ & 0 & $\mathrm{P}$ & 26.77 \\
\hline Chumbinho & $100 \%$ Black & $\mathrm{P}$ & Sf & $\mathrm{Hf}$ & 0 & $\mathrm{P}$ & 23.57 \\
\hline $\begin{array}{l}\text { Vermelhn } \\
\text { Loading [MathJax]/jax/output/C }\end{array}$ & $\begin{array}{l}10 n \% \text { Red } \\
\text { monHTML/fonts/TeX/fontdata.js }\end{array}$ & $\mathrm{P}$ & So & $\mathrm{Hf}$ & 1 & $\mathrm{P}$ & 20.77 \\
\hline
\end{tabular}




\begin{tabular}{|c|c|c|c|c|c|c|c|}
\hline Pombinho & 100\% Brown & $\mathrm{P}$ & Sf & $\mathrm{Hf}$ & 0 & $P$ & 18.77 \\
\hline Vagem Roxa Seca & $100 \%$ Black & $P$ & El & $\mathrm{Hf}$ & 0 & $P$ & 20.03 \\
\hline Mulatinho & $100 \%$ Cream & $\mathrm{P}$ & El & $\mathrm{F}$ & 0 & $P$ & 23.77 \\
\hline Carioca Rosa & 90\% Pinkish e 10\% Brown & $\mathrm{P}$ & Sf & $\mathrm{F}$ & G & $P$ & 17.37 \\
\hline Carijó & 70\% Cream and 30\% Brown & $\mathrm{P}$ & $\mathrm{El}$ & $\mathrm{Hf}$ & 0 & $\mathrm{P}$ & 21.37 \\
\hline Bem-te-vi & $80 \%$ Cream and $20 \%$ Brown & $\mathrm{P}$ & $\mathrm{El}$ & $\mathrm{F}$ & 0 & $\mathrm{P}$ & 20.43 \\
\hline Campos Gerais & $80 \%$ Cream and $20 \%$ Brown & $\mathrm{P}$ & $\mathrm{El}$ & $\mathrm{Hf}$ & 0 & $\mathrm{P}$ & 21.07 \\
\hline ANFC 9 & $\begin{array}{l}80 \% \text { Cream and } 20 \% \text { Light } \\
\text { Brown }\end{array}$ & $P$ & El & $\mathrm{Hf}$ & 0 & $P$ & 21.90 \\
\hline Nhambu & 100\% Black & $\mathrm{P}$ & El & $\mathrm{Hf}$ & 0 & $\mathrm{P}$ & 22.23 \\
\hline Bola Cheia & $80 \%$ Cream and $20 \%$ Brown & $\mathrm{P}$ & El & $\mathrm{Hf}$ & 0 & $\mathrm{P}$ & 25.00 \\
\hline Quero-quero & $80 \%$ Cream and $20 \%$ Brown & $\mathrm{P}$ & $\mathrm{EI}$ & $\mathrm{Hf}$ & 0 & $\mathrm{P}$ & 23.37 \\
\hline BRS Esteio & $80 \%$ Cream and $20 \%$ Brown & $\mathrm{P}$ & $\mathrm{El}$ & $\mathrm{F}$ & 0 & $\mathrm{P}$ & 22.87 \\
\hline BRS Dama & $\begin{array}{l}80 \% \text { Cream and } 20 \% \text { Light } \\
\text { Brown }\end{array}$ & $\mathrm{P}$ & $\mathrm{El}$ & $\mathrm{Hf}$ & 0 & $P$ & 20.17 \\
\hline BRS Expedito & 100\% Black & $\mathrm{P}$ & El & $\mathrm{Hf}$ & 0 & $\mathrm{P}$ & 21.40 \\
\hline $\begin{array}{l}\text { P: Present; A: Absent; Sf: } \\
\text { Glossy; }\end{array}$ & Elliptical; So: Short oblong; Ob: Ob & & i-fla & & & & te; G: \\
\hline
\end{tabular}

Table 4 Data for size of the amplified fragments, number of alleles detected and polymorphism in content (PIC) of ten microsatellites. 


\begin{tabular}{|lllll|}
\hline$N^{\circ}$ & SSR nomenclature & Size of amplified fragments & Number of alleles & PIC \\
\hline 01 & SSR-IAC67 & $102-108$ & 4 & 0,63 \\
02 & SSR-IAC183 & $182-200$ & 5 & 0,66 \\
\hline 03 & SSR-IAC268 & $186-200$ & 3 & 0,33 \\
\hline 04 & SSR-IAC245 & $186-204$ & 5 & 0,55 \\
\hline 05 & SSR-IAC284 & $202-208$ & 4 & 0,58 \\
\hline 06 & SSR-IAC262 & $202-210$ & 5 & 0,60 \\
\hline 07 & SSR-IAC276 & $186-206$ & 6 & 0,65 \\
\hline 08 & SSR-IAC282 & $292-298$ & 4 & 0,61 \\
\hline 09 & SSR-IAC65 & $296-298$ & 2 & 0,37 \\
\hline 10 & SSR-IAC239 & $202-208$ & 4 & 0,63 \\
\hline
\end{tabular}

Figures 

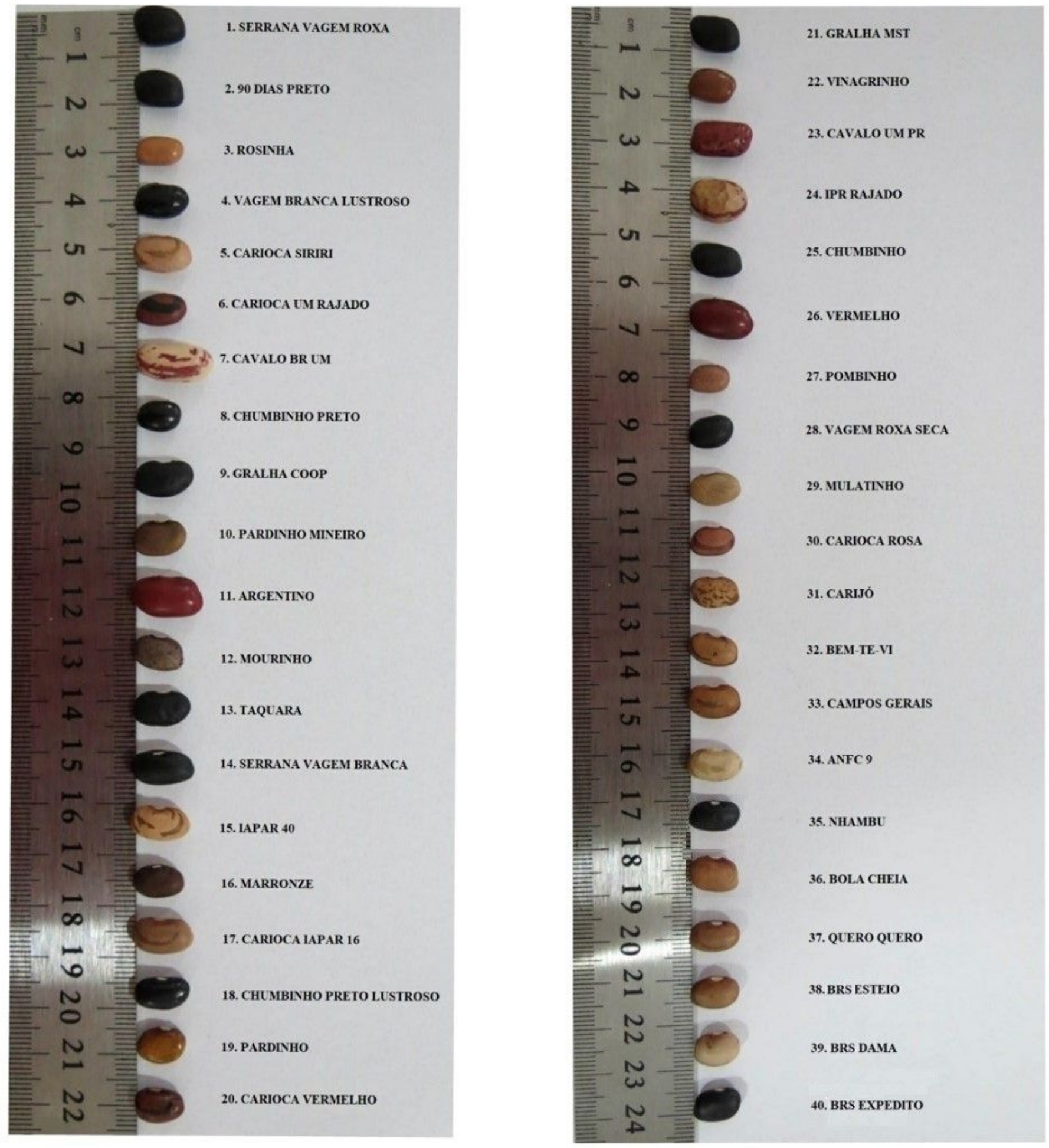

\section{Figure 1}

Seeds of the 40 Common Bean genotypes used in this work, with 31 land races varieties (1 to 31 ) and 9 commercial cultivars (32 to 40 ). 


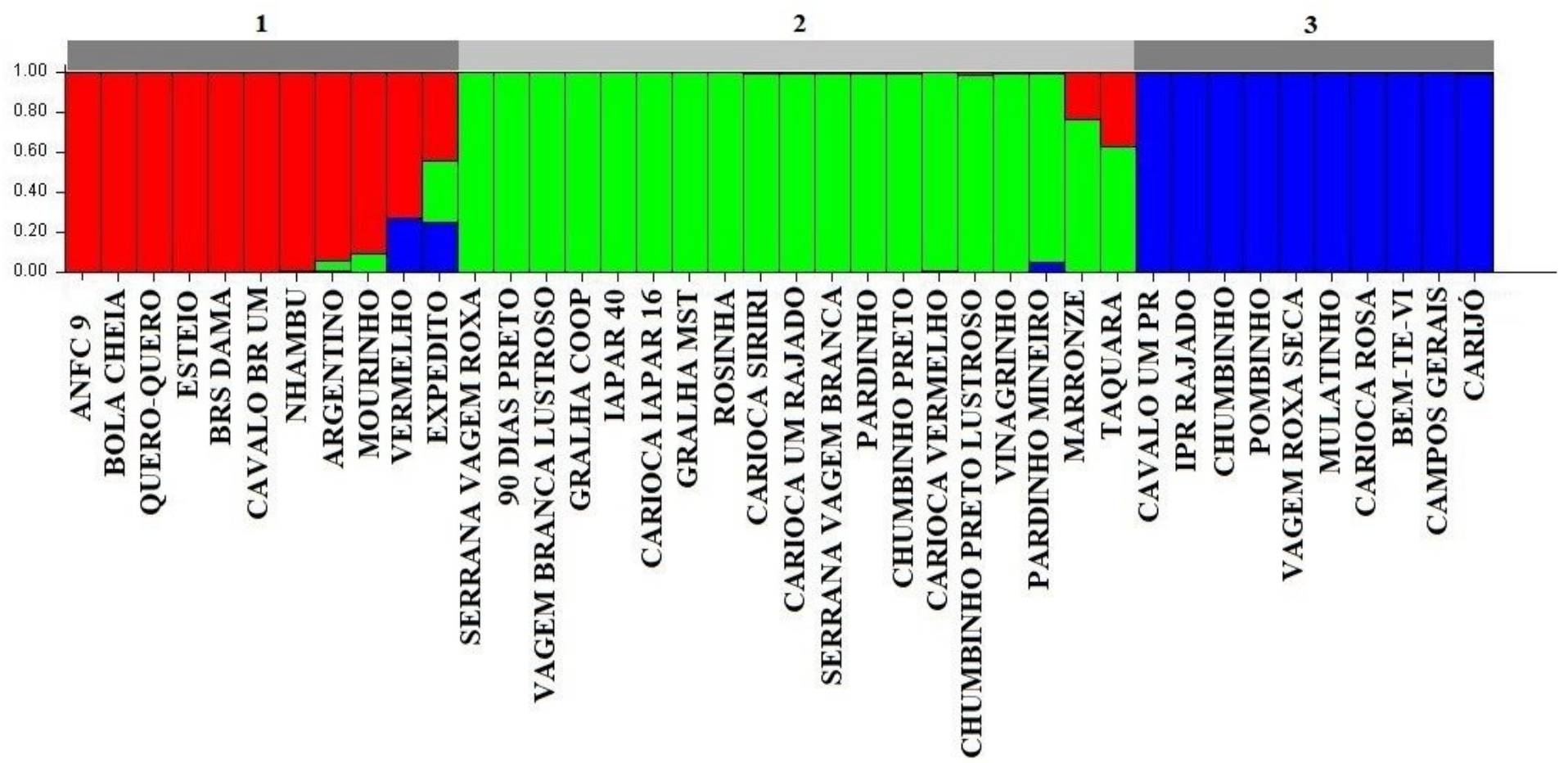

Figure 2

Representation of the forty common bean genotypes according to the Bayesian inference of the Structure program. The evaluated accessions were divided into 3 groups $(K=3)$. The accesses are represented by the colored bars. The same color in different accesses indicates that they belong to the same group. Different colours in the same genotype indicate the percentage of the genome shared with each group. Gray bars represent the groups found 


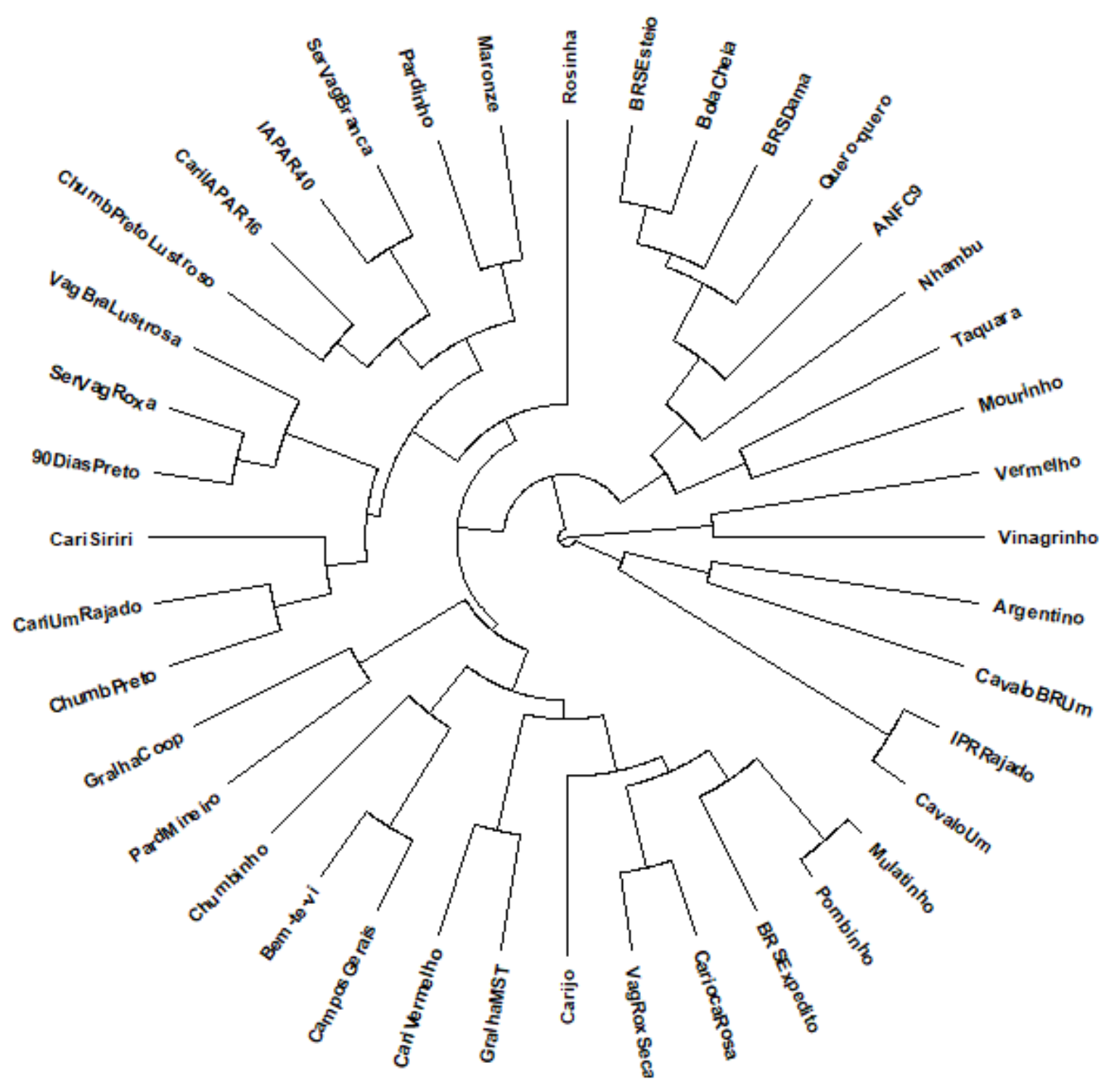

Figure 3

Dendrogram of the forty common bean genotypes, generated from the UPGMA data analysis with the genotyping performed with the ten polymorphic microsatellite markers. 